\section{Reducing the Risk}

of Gynecologic Cancer

in Hereditary Breast Ovarian

Cancer Syndrome Mutation

Carriers: Moral Dilemmas

and the Principle of Double Effect
The Linacre Quarterly 2018, Vol. 85(3) 225-240

(C) Catholic Medical Association 2018 Article reuse guidelines: sagepub.com/journals-permissions DOI: $10.1177 / 0024363918788340$ journals.sagepub.com/home/lqr

\author{
Murray Joseph Casey, MD, MS, MBA, PhD \\ and Todd A. Salzman, PhD, MA, STB
}

\begin{abstract}
Hereditary breast ovarian cancer $(\mathrm{HBOC})$ syndrome is an autosomal dominant disease linked to mutations in the BRCAI and BRCA2 genes in 90 percent of affected families. Female mutation carriers are highly susceptible to aggressive, often disseminated, usually fatal pelvic-abdominal carcinomatosis. This cancer risk can be markedly reduced by surgical removal of the internal gynecologic organs before the end of the fourth decade of life and by using estrogen-progestin formulations marketed for many years as combined oral contraceptives (COCs). Both risk-reducing methods are associated with unfavorable effects. Relying on the principle of double effect, this essay argues for the ethical justification of prophylactic surgery and the use of $\mathrm{COC}$ to reduce the risk of gynecologic cancer in HBOC syndrome mutation carriers.
\end{abstract}

Summary: Hereditary breast ovarian cancer syndrome is an autosomal dominant disease linked to mutations in the BRCAI and BRCA2 genes in most affected families. Female mutation carriers are highly susceptible to aggressive, often disseminated, usually fatal pelvic-abdominal carcinomatosis. This cancer risk can be markedly reduced by surgical removal of the internal gynecologic organs before the end of the fourth decade of life and by using estrogen-progestin formulations marketed for many years as combined oral contraceptives. Both riskreducing methods are associated with unfavorable effects. Relying on the principle of double effect, this essay argues for the ethical justification for those unfavorable effects.

\title{
Keywords
}

Double effect, Hereditary gynecologic cancer, Moral dilemmas, Oral contraceptives, Prevention, Risk-reduction, Treatment

Women from families with a history of hereditary breast ovarian cancer (HBOC) syndrome who inherit autosomal dominant, cancer-linked mutations in their $B R C A 1$ or $B R C A 2$ genes bear a disturbingly high risk for disseminated, usually fatal gynecologic cancers (Boyd et al. 2000; Casey and Colanta 2016; Finch et al. 2014; Lux, Fasching, and Beckmann 2006; Lynch et al. 2009; Petrucelli, Daly, and
Creighton University, Omaha, NE, USA

\section{Corresponding Author:}

Murray Joseph Casey, MD, MS, MBA, PhD, Creighton University, 77I0 Mercy Road, Suite 602, Omaha, NE 68124, USA.

Email: mjcasey@creighton.edu 
Feldman 2010). Mutations in one or another of these genes have been linked to cancers in 90 percent of HBOC syndrome families (Ford et al. 1998). Inheritance of cancer-linked BRCA1 mutations conveys a cumulative risk to age seventy years of 47-66 percent for breast cancer and 35-46 percent for ovarian cancer, and inheritance of cancer-linked mutations in $B R C A 2$ conveys a cumulative risk to age seventy years of 40-57 percent for breast cancer and 13-23 percent for ovarian cancer (Chen and Parmigiani 2007). If lifetime risks were calculated beyond this, the risks for these cancers could be higher.

Although the exact primary gynecologic organ from which pelvic carcinomas originate in $B R C A 1$ and $B R C A 2$ mutation carriers often cannot be determined, initially and for many years they were believed to transform from ovarian epithelium, and thus the designation, "ovarian" cancers. However, there is accumulating evidence that many, if not most, pelvic carcinomas in $B R C A 1$ and $B R C A 2$ mutation carriers actually arise from precursor lesions in fallopian tube epithelium (Casey and Colanta 2016; Singh et al. 2015). The majority of gynecologic cancers in $B R C A 1$ and $B R C A 2$ mutation carriers are high-grade serous or anaplastic carcinomas (Casey et al. 2013; Lynch et al. 2009; Piek et al. 2003). Recent research has demonstrated that pathogenesis of pelvic, high-grade serous carcinoma (HGSC) is characterized by a very high 96 percent to perhaps 100 percent rate of TP53 gene mutations (Ahmed et al. 2010; Cancer Genome Atlas Research Network 2011; Kurman et al. 2014; Vang et al. 2016). Recently, high-grade pelvic-abdominal carcinomatosis containing TP53 mutations but with histomorphology other than characteristic HGSC has been described with predominant or mixed solid, endometrioid, and/or transitional (SET) carcinoma elements (Howitt et al. 2015; Karnezis et al. 2013; Soslow et al. 2012). Pelvic carcinomas with highgrade SET morphology may be more frequent in $B R C A 1$ and $B R C A 2$ mutation carriers than sporadic cases (Howitt et al. 2015; Ritterhouse et al. 2016; Soslow et al. 2012), and we have found immunohistochemical p53 confirmed high-grade transitional cell-like and endometrioid SET carcinomas involving the fimbria and distal fallopian tubes of $B R C A 1$ mutation carriers. Current evidence supports the likelihood that the preponderance of pelvicabdominal HGSC and high-grade SET carcinomas in $B R C A 1$ and $B R C A 2$ mutation carriers arise from the müllerian-derived epithelium of the fallopian tubes, endometrium, and perhaps the endocervix, although the origin of some cases from peritoneum or ovarian surface epithelium is not ruled out (Casey and Colanta 2016; Casey et al. 2015; Lux, Fasching, and Beckmann 2006; Singh et al. 2015).

Like many, perhaps most, hereditary syndromes, inheritance of the genetic defect in $B R C A 1$ or $B R C A 2$ mutation carriers from HBOC syndrome families is the essence of this disease, which for those with increased lifetime cancer risks may not be clinically manifested for many years. Indeed, the nearly ubiquitous frameshift and nonsense mutations in TP53 that result in selective clonal selection of preneoplastic and neoplastic cells and loss of tumor suppression that characterize the highly aggressive, frequently disseminated gynecologic carcinomas that characterize HBOC syndrome may be late events in the mutagenic carcinogenesis of these cancers (Casey and Colanta 2016; Greenblatt et al. 1994). However, TP53 mutations identical to those found in ovarian HGSC have been demonstrated in noninvasive, intraepithelial neoplastic serous lesions in the fallopian tubes of $B R C A 1$ and $B R C A 2$ mutation carriers with no clinical signs or symptoms of gynecologic or intra-abdominal carcinomatosis (Casey and Colanta 2016; Crum, McKeon, and Xian 2012). When TP53 mutations have been analyzed in serous tubal intraepithelial carcinomas and associated remote tumors, the same mutations were found (Crum, McKeon, and Xian 2012). Some highly regarded investigators believe that many or most of these lesions may be preceded by "p53 signatures" in otherwise normal appearing fallopian tube epithelium (Crum, McKeon, and Xian 2012).

Ovarian cancers in members of HBOC syndrome families tend to occur or be diagnosed at younger ages, typically a decade earlier than sporadic ovarian cancers (Boyd et al. 2000; Petrucelli, Daly, and Feldman 2010; Weiderpass and Tyczynski 2015). Precursor lesions to HGSC and occult invasive HGSC have been reported in prophylactically removed specimens from women as young as nineteen years and often in women in their third and fourth decades (Gross et al. 2010).

Women with family histories of breast and/or ovarian cancers but without cancer-linked $B R C A 1$ or $B R C A 2$ germline mutations also may be at increased risk for ovarian cancer (Lux, Fasching, and Beckmann 2006; Weiderpass and Tyczynski 2015), and ongoing research continues to yield discoveries of multiple newly recognized genetic loci linked to susceptibility for ovarian cancer (Phelan et al. 2017).

Considering the morbidities and high mortality rates associated with gynecologic cancer in HBOC syndrome mutation carriers, reducing the risk of this disease is a high priority for those engaged in gynecologic oncology investigation and clinical practice. This essay presents a brief review of relevant recent 
publications concerning possible risk factors and strategies for reducing the risk of gynecologic cancer in HBOC syndrome mutation carriers. The riskreducing strategies holding greatest promise involve individualized clinical judgments and possible moral dilemmas from a Catholic perspective that are ethically justified by the principle of double effect.

\section{Risk-Reducing Strategies}

\section{Risk-Reducing Surgery}

The most tried and true approach for reducing the risk of gynecologic cancers in HBOC syndrome mutation carriers has been prophylactic oophorectomy and/or salpingo-oophorectomy at least by age forty years, which also reduces the risk of breast cancer in these women (Casey and Colanta 2016; Finch et al. 2014; Kauff et al. 2002; Lux, Fasching, and Beckmann 2006; Rebbeck et al. 2002; Petrucelli, Daly, and Feldman 2010; Snyder, Casey, and Lynch 2015). A meta-analysis of data from publications between January 1999 and December 2007 concluded that salpingo-oophorectomy reduced the risk of ovarian cancers by at least 80 percent and breast cancer by 50 percent in BRCA1 and BRCA2 mutation carriers (Rebbeck, Kauff, and Domchek 2009). Early premenopausal risk-reducing salpingo-oophorectomy (RRSO) is especially important for $B R C A 1$ mutation carriers. In a large international study, forty-four occult gynecologic or peritoneal cancers were found in 1,057 BRCA1 mutation carriers undergoing preventive oophorectomy for a prevalence of 4.16 percent to and beyond age seventy years (Finch et al. 2014). Ninety-eight overt gynecologic or peritoneal cancers were clinically diagnosed in $B R C A 1$ mutation carriers with intact ovaries; 2 percent were diagnosed before age thirty-five years, 8 percent before age forty-five years, and 52 percent before age fifty years (Finch et al. 2014). The lifetime 0.6 percent prevalence of occult gynecologic cancers discovered with preventive oophorectomy was lower and the ages for diagnosing all gynecologic or peritoneal cancers were higher in $B R C A 2$ mutation carriers with only one of the ten being diagnosed before age fifty years (Finch et al. 2014). The risk of gynecologic cancer can be maximally reduced by extending prophylactic surgery to include hysterectomy along with RRSO, thereby removing all müllerian-derived epithelium of the endocervix, endometrium, endosalpinx, and potentially involved ovaries and para-ovarian peritoneum (Casey et al. 2015; Casey and Colanta 2016; Falconer et al. 2015; Poole et al. 2015). However, both of these operations eliminate the woman's capacity for childbearing, and removal of the ovaries induces surgical menopause.

Concerns regarding vasomotor symptoms, sexual function, and possible increased risks for cardiovascular diseases and osteoporosis in women who undergo premature surgical menopause are relevant and appropriate when counseling and considering the cancer prophylaxis effects of RRSO (Finch, Evans, and Narod 2012, Marchetti et al. 2014a, 2014b; Rivera et al. 2009). These are very complex and unresolved issues. While there are no longterm randomized studies to test those outcomes in $B R C A 1$ and BRCA2 mutation carriers who have undergone RRSO with or without hysterectomy, contemporary comprehensive reviews demonstrate and conclude that properly prescribed, short-term hormone replacement therapy (HRT) in mutation carriers can alleviate hot flushes and vaginal dryness and does not attenuate the favorable protective effects of this preventive surgery against breast and ovarian cancers (Casey and Colanta 2016; Finch, Evans, and Narod 2012; Marchetti et al. 2014a, 2014b). Thus far, studies have not specifically addressed the cardiovascular effects of premenopausal RRSO in BRCA1 or BRCA2 mutation carriers, though in general populations it is clear that HRT protects against the adverse cardiovascular events associated with early surgical menopause (Finch, Evans, and Narod 2012; Rivera et al. 2009; Schierbeck et al. 2012). Accelerated bone loss was confirmed in retrospective studies of $B R C A 1$ and $B R C A 2$ mutation carriers who had undergone RRSO; however, these studies are confounded by the inclusion of patients already diagnosed and treated for breast cancer, and a minority of the subjects had received HRT. Also, patients in those studies were somewhat older (mean age forty-nine years and median age fifty-seven years, respectively) than the subjects of a prospective study, which found no differences compared to the population norms for objective measurements of bone density or fracture incidence in BRCA1 $(n=121)$ and BRCA2 $(n=$ $60)$ mutation carriers and members of HBOC families $(n=31)$ who underwent RRSO at median age forty-two years (range thirty to fifty-two years; Fakkert et al. 2015). Although the latter study, as well, included patients diagnosed and treated for breast cancer, 84 percent of all subjects were premenopausal at the time of RRSO, and 47 percent had received HRT. Despite the lack of randomized prospective trials, meta-analysis of prospective studies determined, ultimately, that RRSO is associated with highly significant $(p<.00001)$ reductions of all- 
cause mortality in both $B R C A 1$ and $B R C A 2$ mutation carriers (Marchetti et al. 2014a), and at least in the short term, HRT seems to improve the quality of life and lessen the untoward effects of premature surgical menopause without negating the protective effect of oophorectomy on subsequent breast cancer (Eisen et al. 2008; Kotsopoulos et al. 2018; Marchetti et al. 2014b; Rebbeck et al. 2005).

\section{Combined Oral Contraceptives (COCs)}

Because of the protective effect of particular estrogen-progestin formulations against ovarian cancer in general populations (American College of Obstetricians and Gynecologists [ACOG] 2006; Cibula et al. 2010; Collaborative Group on Epidemiological Studies of Ovarian Cancer [CGESOC] 2008; Hannaford et al. 2010; Maquire and Westhoff 2011; Schildkraut et al. 2002; Tung et al. 2005; Vessey, Yeates, and Flynn 2010), the use of these medications has been suggested to reduce the very high risk for ovarian carcinoma in HBOC syndrome mutation carriers (ACOG 2006, 2009, 2010; CGESOC 2008; Petrucelli, Daly, and Feldman 2010). These preparations have been developed and marketed for many years because their hormonal effects combine to prevent pregnancy; hence, they are commonly and medically termed COCs.

Although an early study of Israeli Jewish women with ovarian cancer who carried founder-specific mutations in BRCA1 (185delAG and 5382insC) or $B R C A 2$ (6174delT) found no significant protective effects associated with the use of oral contraceptives (Modan et al. 2001), multiple well-conducted subsequent studies have demonstrated very significant reductions in the risk of ovarian cancer in $B R C A 1$ and $B R C A 2$ mutations carriers using $\mathrm{COC}$ for at least one year, and increasing years of COC use were associated with further decreasing ovarian cancer risks (Cibula et al. 2014; Finch et al. 2014; Friebel, Domchek, and Rebbeck 2014; Iodice et al. 2010; Kotsopoulos et al. 2015; McLaughlin et al. 2007; Milne et al. 2005; Moorman et al. 2013; Whittemore et al. 2004).

The biologic mechanism for the preventive effect of COC against ovarian cancer is not fully determined (Schildkraut et al. 2002), but in general population epidemiologic studies, there is evidence that the risk for ovarian cancer is significantly increased with lifetime numbers of uninterrupted ovulations, and this risk is greatest in younger ovulatory women (Purdie et al. 2003; Tung et al. 2005). However, the risk for ovarian cancer is reduced by factors that suppress ovulation, including COC, pregnancy, and lactation (Purdie et al. 2003; Schildkraut et al. 2002; Tung et al. 2005). Whatever the biological mechanism of COC prevention and the contribution of progestin potency against ovarian cancer, population-based studies found that the association with ovarian cancer risk-reduction has been retained by the currently most commonly prescribed low-estrogen formulations at doses which continue to suppress ovulation (Ness et al. 2000; Schildkraut et al. 2002).

Some general population studies have raised concerns of possible increased breast cancer risk with the use of COC (ACOG 2006, 2009; Cibula et al. 2010; Collaborative Group on Hormonal Factors in Breast Cancer 1996; ESHRE Capri Workshop Group 2004; Kahlenborn et al. 2006; Kocjan and Prelevic 2003; Narod 2011), though other studies failed to confirm an association of present or former use of COC with increased risks for breast cancer in the general population and also in women with family histories of breast cancer (Marchbanks et al. 2002; Milne et al. 2005; Vessey and Painter 2006). When $B R C A 1$ and BRCA2 mutation carriers were studied for associations of COC use with breast cancer risks, the results varied (Brohert et al. 2007; Milne et al. 2005; Narod et al. 2002). Some investigators actually found that COC use was associated with significantly reduced risk for early-onset breast cancer before age forty years in $B R C A 1$ mutation carriers though not in $B R C A 2$ mutation carriers (Milne et al. 2005), while others found no increased risk for breast cancer in BRCA2 mutation carriers but modestly increased risk in $B R C A 1$ mutation carriers (Narod et al. 2002), and still other investigators found increased risks for breast cancer in both $B R C A 1$ and BRCA2 mutation carriers with COC use (Brohet et al. 2007). Because women without $B R C A 1$ or BRCA2 mutations who used COC since 1975 had significantly lower risk for breast cancer compared with noncarriers using COC prior to 1975 (Milne et al. 2005), and a multinational matched case-control study found significantly increased breast cancer risk in BRCA1 mutation carriers who began COC use prior to 1975 (Narod et al. 2002), those investigators suggested this may be due to the higher-dose hormone formulations used during the earlier years compared with mostly lowdose COC used in more recent years (Milne et al. 2005; Narod et al. 2002). These findings were challenged by a later international matched case-control study, which found significantly increased risks for breast cancer in both $B R C A 1$ and $B R C A 2$ mutation carriers who used COC either before or after 1975 (Brohet et al. 2007). A subsequent meta-analysis of 
oral contraceptive use in 2,855 HBOC syndrome mutation carriers previously diagnosed with breast cancers concluded that oral contraceptive formulations used before 1975, indeed, were associated with significantly increased risks for breast cancer in HBOC syndrome mutation carriers, but "no evidence of significant association was found with use of more recent formulations" (Iodice et al. 2010).

A matched case-control study of 2,492 BRCA1 mutation carriers from Europe and North America, which gave no parameters as to era during which $\mathrm{COC}$ were used, did find a significant association with early-onset breast cancers diagnosed before age forty years in patients who began COC use before age twenty years and a possible trend toward earlyonset breast cancer when $\mathrm{COC}$ use was prior to age twenty-five years (Kostopoulos et al. 2014). However, this investigation did not demonstrate any association with $\mathrm{COC}$ use and breast cancer diagnosed at age forty years and older in BRCAl mutation carriers, and the investigators found no relationship at all between COC use and breast cancer risk in $B R C A 2$ mutation carriers (Kostopoulos et al. 2014). A recently published Italian study of 1,541 women at high risk for breast cancer because of defined strong family histories or personal history of multiple and/or early-onset breast and/or ovarian cancer and 113 BRCA1 and BRCA2 mutation carriers found no increased breast cancer with $\mathrm{COC}$ use in either group (Toss et al. 2017).

Critical of the inconsistent findings of studies which examined breast cancer risk factors among affected and unaffected BRCA1 and BRCA2 mutation carriers in matched case-control studies, a collaborative multi-institutional United States-Australian study compared the use of COC in 487 BRCAI (283) and $B R C A 2$ (204) mutation carriers with breast cancer to 894 mutation-negative breast cancer patients and found no significant difference or evidence of trends to increasing risk for breast cancer in mutation carriers with duration of use (Moorman et al. 2010). The authors of recent meta-analyses of oral contraceptive use and risk for breast cancer in HBOC syndrome mutation carriers comment on the diversity of methodologies used in the various reports, inconsistent results, and inconclusive evidence for relationships between COC use by BRCA1 and BRCA2 mutation carriers and breast cancer risk (Cibula et al. 2014; Friebel, Domchek, and Rebbeck 2014; Iodice et al. 2010; Moorman et al. 2013). These meta-analyses concluded that evidence from the data collected from published investigations, critically considered, was insufficient to conclude that COC use affected the risk for breast cancer in $B R C A 1$ or
BRCA2 mutation carriers (Cibula et al. 2014; Friebel, Domchek, and Rebbeck 2014; Iodice et al. 2010; Moorman et al. 2013).

\section{Childbearing and Breastfeeding}

General population studies have abundantly demonstrated the protective effect of childbearing and inverse correlation with total duration of breastfeeding against breast cancer (ESHRE Capri Workshop Group 2004). The current Italian study of 113 patients at very high risk for breast cancer because they carried $B R C A 1$ and $B R C A 2$ mutations, just cited above, found that parity protected against breast cancer, protecting ever more progressively up to at least three pregnancies (Toss et al. 2017). But other reports conflict regarding the effects of childbearing on breast cancer risks in BRCA1 and BRCA2 mutation carriers (Andrieu et al. 2006; Cullinane et al. 2005; Jernström et al. 1999; Milne et al. 2010).

A multinational, matched case-control study of 236 BRCA1 and BRCA2 mutation carriers found that childbearing significantly increased the risk of breast cancer diagnosis before age forty years, and the risk for breast cancer increased significantly with each additional pregnancy up to three or more (Jernström et al. 1999). On the other hand, an international cohort study of $602 B R C A 1$ and $251 B R C A 2$ mutation carriers with breast cancer compared with 585 BRCA1 and 163 BRCA2 mutation carriers unaffected with breast cancer found no significant difference in the risks for breast cancer between parous and nulliparous women with either a $B R C A 1$ or a $B R C A 2$ mutation (Andrieu et al. 2006). Another multinational, matched case-control study of 1,260 BRCA1 (934) and BRCA2 (326) mutation carriers found that while parity per se had no overall effect on breast cancer risk, there was a 36 percent reduction of breast cancers in BRCA1 mutation carriers who had four or more children (Cullinane et al. 2005). In contrast, this study found that increasing parity was associated with a significantly increased risk for breast cancer in $B R C A 2$ mutation carriers (Cullinane et al. 2005). Although the effect of parity compared with nulliparity did not reach significance in a collaborative Spanish study of 515 BRCA1 and $503 B R C A 2$ mutation carriers, there was an increasing trend toward breast cancer protection per live birth in BRCA1 mutation carriers but not in BRCA2 mutation carriers; and there was no evidence that younger ages of childbearing were protective in either $B R C A 1$ or $B R C A 2$ mutation carriers (Milne et al. 2010). In addition, no differences in mean ages of first full-term childbirths were found in an 
international, case-control study of 1,853 BRCA1 and $B R C A 2$ mutation carriers with breast cancer matched with 1,853 unaffected mutation carriers (Kotsopoulos et al. 2007).

There is some evidence that parity and breastfeeding may be protective against breast cancer and perhaps also ovarian cancer in $B R C A 1$ mutation carriers, but not necessarily in $B R C A 2$ mutation carriers (Andrieu et al. 2006; Fishman 2010; Friebel, Domchek, and Rebbeck 2014; Kotsopoulos et al. 2015; Toss et al. 2017). An international study of reproductive factors in 798 BRCAI (670) and BRCA2 (128) mutation carriers found that parity was associated with significant reduction of the risk for ovarian cancer in $B R C A 1$ mutation carriers but increased the ovarian cancer risk in $B R C A 2$ mutation carriers (McLaughlin et al. 2007). The Spanish study of 1,018 BRCA1 (515) and BRCA2 (503) mutation carriers similarly found reduced risk for ovarian cancer in $B R C A 1$ mutation carriers but no significant association with ovarian cancer risk in $B R C A 2$ mutation carriers (Milne et al. 2010). Thus, interpretable data from investigations of the effects of parity and breastfeeding on the risks for breast and ovarian cancers in BRCA1 and BRCA2 mutation carriers are so far limited and too imprecise for clinical counseling and application (Fishman 2010).

To summarize, only risk-reducing surgery, preferably by age thirty-five years and certainly before the end of the fourth decade, and the use of COC have been demonstrated to effectively reduce the risk of müllerian-derived pelvic-abdominal carcinomatosis in HBOC syndrome mutation carriers. Both options present ethical dilemmas for mutation carriers and their physicians and counselors who intend to abide by Catholic teaching against sterilization and contraception (United States Conference of Catholic Bishops [USCCB] 2009, dirs. 52-53). The first of these strategies renders the women infertile and menopausal, and the second prevents ovulation and may be attended with foreseeable untoward health effects.

\section{Strategic Planning}

Women with increased risks for müllerian HGSC, whether linked to $B R C A 1$ or $B R C A 2$ mutations or one of the increasing numbers of familial susceptibility loci (Ford et al. 1998; Phelan et al. 2017), should be engaged in cancer genetics consultation at an early age, at least by age eighteen years, if possible (ACOG 2009; Daly et al. 2010). Presently available surveillance methods have found no difference in either the stage at diagnosis of sporadic ovarian cancer or ovarian cancer death rates for screened patients compared to control subjects (U.S. Preventive Services Task Force 2012), and results from screening high-risk patients have been likewise disappointing (Evans et al. 2009; Pruthi, Gostout, and Lindor 2010; Skates et al. 2017). Emerging protocols, however, using statistically generated algorithms to determine the change point of rapidly rising serum CA125 tumor marker titers above the individual baseline levels of women at high risk for ovarian cancer might serve to improve the specificity and positive predictive values of transvaginal ultrasound scans for diagnosing early invasive cases with relatively better results and survival than routine serial CA125 and ultrasound screening (Skates 2012; Skates et al. 2017). Given the high prevalence and severity of pelvicabdominal HGSC in HBOC syndrome mutation carriers and others with strong family histories for ovarian cancer, prospectively planned surveillance programs ought to be initiated and continued until these patients proceed with risk-reducing surgery.

Because gynecologic and peritoneal cancers in HBOC syndrome are characterized by early ages of onset (Boyd et al. 2000; Finch et al. 2014; Petrucelli, Daly, and Feldman 2010; Weiderpass and Tyczynski 2015), for greatest effectiveness, risk-reducing surgery should be done before age forty years (or earlier, if childbearing has been completed) for $B R C A 1$ mutation carriers and seriously considered prior to the sixth decade by $B R C A 2$ mutation carriers. Whether limited to RRSO or extended to include hysterectomy, operations to reduce the risk of gynecologic cancers in HBOC mutation carriers terminate a woman's reproductive life. Moreover, $B R C A 1$ and $B R C A 2$ mutation carriers and other women with increased familial risks for gynecologic cancer must face these decisions in a climate of changing educational, occupational, and cultural norms which together with advances in maternalfetal medicine are being accompanied by welldocumented trends to generally later ages of childbearing and extending women's reproductive lives. In the United States, the average age of first childbearing has pushed above age twenty-six years (Mathews and Hamilton 2016). During the fourteen years between 2000 and 2014, while the proportion of first births to teen mothers in the United States decreased from 23.1 percent to 13.4 percent and proportion of births to women between ages twenty and twenty-four years remained at 28.7 percent, the proportion of first births to women ages twenty-five to thirty-four years increased from 24.3 percent to 27 percent, and the proportion of first births to women 
over age thirty-five years increased nearly a quarterfold from 7.4 percent to 9.1 percent (Mathews and Hamilton 2016). In view of the proven efficacy of COC in HBOC mutation carriers and others for reducing the risk of pelvic-abdominal carcinomatosis and the conflicting results from studies of the effects of pregnancy, including early pregnancies, these women are candidates for prophylactic use of COC prior to their first pregnancies, during intervals between pregnancies, and after childbearing until undergoing risk-reducing surgery.

Medical decisions to prevent and treat disease involve weighing and maximizing the probability of benefits and minimizing the possibility of untoward effects (Casey and Salzman 2014). Physicians in counseling and women at high risk for müllerian carcinomatosis must weigh the intended beneficial effects of reducing gynecologic cancer risk with $\mathrm{COC}$ together with the risks of unintended untoward effects and the loss of reproductive capacity and premature menopause with surgery. Particular to these decisions are full disclosure and the patient's understanding of a possible increased risk for breast cancer when $\mathrm{COC}$ use is initiated before age twenty years, the importance of commencing breast cancer education before this age and of beginning annual screening early in the third decade, and cautious attention to coexisting medical conditions, which should limit or prohibit the use of COC (ACOG 2006; Daly et al. 2010; Kostopoulos et al. 2014; Pruthi, Gostout, and Lindor 2010). The goal of all medical decisions is to choose an action that is likely beneficial and to avoid excessive adverse effects of prevention or treatment. When up-to-date, scientifically studied medical judgments favor the use of COC intended to reduce the risk of müllerian carcinomatosis in HBOC syndrome mutation carriers and others with increased familial risk, we believe that, for patients and their prescribing physicians, accepting the unintended contraceptive effects of these preparations is in accord with Catholic teaching and is justified by the principle of double effect (Casey and Salzman 2014).

\section{Prevention, Treatment, and Moral Agency}

Two questions must be addressed before applying the principle of double effect to the prescription and use of $\mathrm{COC}$ intended to reduce the risk of müllerian carcinoma in highly susceptible women. The first question concerns moral agency and asks whether, in applying the principle, there is a significant moral difference between the Catholic physician who prescribes $\mathrm{COC}$ and the married Catholic woman who uses COC (Clark 2014). In response, we do not discern a significant moral difference when the direct intention of either agent is to prevent cancer and the unintended side effect is contraception. In both cases, where an act has both good and bad effects, the agent's moral judgment is subject to evaluation by the principle of double effect to determine whether or not its criteria are met and the act is morally justified. The second question concerns whether there is a moral distinction between treatment and prevention of gynecologic cancer that would allow the use of the principle of double effect in the former case but not in the latter (Clark 2014). Many Catholic biomedical ethicists do not recognize a moral distinction between treatment and prevention of a disease when the criteria of the principle of double effect are met (Cahill 2005, 158-59; Kelly, Magill, and ten Have 2013, 115; Tuohey 1990). Others make a distinction and argue that in the case of treatment, the principle applies, but in the case of prevention it may not apply (Clark 2014). In his 1968 encyclical Humanae vitae, Pope Paul VI (1968) allows for the use of therapies to treat a pathology but does not consider cases of preventing a pathology (no. 15). There are, however, at least two cases, each of which could be justified by the principle of double effect, where the Catholic church has not condemned the use of $\mathrm{COC}$ for prevention rather than treatment. The first case involves women who may be potential victims of rape or who have been raped. Most Catholic ethicists argue for the moral use of COC to prevent pregnancy in cases where rape or sexual assault are possible and in cases where rape has occurred but there is no evidence that fertilization has taken place (Ashley and O'Rourke 1997, 303-04; Grisez 1993, 512; Smith 2016; USCCB 2009, dir. 36). The second case involves the use of COC for Catholic nuns because of their proclivity to dying from breast, ovarian, and uterine cancer (Britt and Short 2012; Fraumeni et al. 1969). Here, the risks are substantially lower for nuns than the risks for these cancers in BRCA1 and BRCA2 mutation carriers, especially for women of younger ages (Chen and Parmigiani 2007; Britt and Short 2012). In both cases, the use of $\mathrm{COC}$ for prevention, either for prevention of a disease or prevention of a pregnancy, rather than treatment, is morally justified by the principle of double effect.

One may challenge our claim that there is not a significant moral distinction between treatment and prevention by asserting that treatment is for an existing pathology, whereas prevention is for a possible disease or conception due to rape. Our response is 
threefold. First, considering the possible origins of the principle of double effect and its application to self-defense by St.Thomas Aquinas (2008, II-II, q. 64., a.7; Ghoos 1951; Mangan 1949), it was developed to prevent the injury or death of an innocent person, not to treat that person. Prevention is at the very heart of the origins and application of the principle of double effect in the Catholic tradition (Keenan 1993). The burden of proof is on those who would use it to justify only treatment and not justify prevention. Second, the possibility of women being raped and the possibility of nuns or any woman contracting a malignant cancer are based on probabilities, just as successful treatment with $\mathrm{COC}$ of a pathology is a probability. Third, the Catholic tradition has never required certain knowledge in order to make a moral judgment. This qualification applies to the knowledge of whether using $\mathrm{COC}$ will treat a pathology or prevent a possible disease. When dealing with indeterminacies, the relative probability that a moral agent needs to justify an act with good effects (i.e., use of arms to prevent an innocent death or using COC to prevent disease or pregnancy in the case of rape) but also foreseeable bad effects (i.e., killing a human person or suppressing ovulation in an otherwise potentially fertile woman) are judgments that must be determined according to the moral agent's well-informed conscience (Vatican Council II 1965a, no. 3; Vatican Council II 1965b, no. 16).

One may also challenge our claim based on the definition of the object of the act that defines the moral act, arguing that the object of these acts to prevent pregnancy from possible or actual rape or to prevent gynecologic cancers results in ovulatory suppression, which is contraceptive. According to the 1993 encyclical of Pope John Paul II, Veritatis splendor, "The morality of the human act depends primarily and fundamentally on the 'object' rationally chosen by the deliberate will ... By the object of a given moral act... one cannot mean a process or an event of the merely physical order, to be assessed on the basis of its ability to bring about a given state of affairs in the outside world." Rather, "to grasp the object of an act which specifies that act morally, it is therefore necessary to place oneself in the perspective of the acting person" (John Paul II 1993, no. 78; emphasis in original). If the perspective of the acting person is contraceptive then the object of the moral act is contraception and morally prohibited (Paul VI 1968, no. 11). The perspective of the acting person in the cases above, however, and therefore the object of the act, is the decision to use COC to prevent pregnancy if rape is possible or has occurred or to prevent or reduce the risk of gynecologic cancers and to preserve health. In both cases, the object of the act is not contraception, though the bad effect of taking COC is anovulation. The decision to prescribe or use $\mathrm{COC}$, which includes the bad effect, is justified by the principle of double effect.

\section{Applying the Principle of Double Effect}

Having clarified our position regarding the use of $\mathrm{COC}$ for treatment and prevention and the distinction between agents who prescribe or use COC, physicians or patients, respectively, we now will discuss applications of the principle of double effect to moral decisions that arise when considering strategies for reducing the high risk of gynecologic cancer in HBOC syndrome mutation carriers.

The sorts of counseling and therapeutic decisions which physicians make every day and patients' decisions that follow those recommendations should subscribe to the first precept of natural moral law, "do good and avoid evil" (Aquinas 2008, I-II, q. 94, a. 2). Catholic moral teaching is grounded in the natural philosophy that through reason and critical reflections on human experience, persons have the ability to know what is good and have the freedom and capacity to do what is right and just (Aquinas 2008, I-II, q. 91, a. 2; I-II, q. 93; I, q. 83, aa.1-4; Catechism of the Catholic Church [CCC] 1994, no. 1730; Casey and Salzman 2014).

While some human acts are always morally evil, such as directly killing an innocent person, since a directly intended evil act can never be justified even by potentially good outcomes (CCC 1994, nos. 1759-89), most human actions have multifold effects, some good and intended and some bad and foreseeable but unintended (Casey and Salzman 2014). To fulfill the first principle of natural lawdo good and avoid evil - the intention of acts which are good or at least neutral must be the good effects, while the possibility of unintended but foreseeable bad effects must be justified (Aquinas 2008, II-II, q. 64, a. 7; Ashley and O'Rourke 1997, 191-92; Gillon 1986; Grisez 1965; Gula 1989, 270-72; O'Donnell 1991, 2-3, 30-36). The principle of double effect, which consists of four criteria, is used to justify an act with both good and bad effects: "(1) the act in itself must not be morally wrong; (2) the bad effect must not cause the good effect; (3) the agent must not intend the bad effect (as an end to be sought); (4) the bad effect must not outweigh the good effect"; that is, there must be a proportionate reason to justify the bad effect (Kelly, Magill, and 
ten Have 2013, 105). Gillon and others (1986) add a fifth criterion: (5) there must be no better alternative (Keenan 1993; O'Donnell 1991, 26-30).

Applying these criteria to the counsel, prescription, and use of $\mathrm{COC}$ with the intention of reducing the risk of müllerian carcinomatosis in highly susceptible women, the first criterion justifies prescribing or using COC since it is a neutral act - in itself, prescribing or using COC is neither good nor bad. According to the second criterion, the good effect of the act of prescribing and using $\mathrm{COC}$ is to prevent the development of pelvic and disseminated fatal cancer, which from our review probably arose as occult lesions prior to or during the third decade of life in many susceptible women, and to prolong the reproductive lives and lessen the burdens of premature surgical menopause. While prescribing and using COC could result in disabling or fatal adverse effects in a few women even if cases are knowledgably and carefully selected for treatment and because the preparations suppress ovulation, the possible bad physical and contraceptive effects are not the means to the good effect. This applies to both treatment and prevention. Although the good and bad effects may be more contemporaneous in treatment than in prevention, in neither case are the bad effects the means to the good effect. Considering the third criterion, the direct intention of prescribing and using COC is to lessen the risk of cancer while prolonging the reproductive years and delaying the symptoms and debilitation of premature surgical menopause in well-selected patients. The possible adverse physical effects and intervals of contraception with COC prescription and use are foreseeable but unintended. The fourth criterion - the bad effect must not outweigh the good effect-is the most complex criterion to apply in the principle of double effect when making moral judgments. The ethical principle of proportionate reason is used to establish the relationship between the directly intended morally good effects of an action and unintended but foreseeable bad effects (McCormick 1981; Walter 1990). The expressions "proportionate benefit" and "proportionate reason" are used in the Ethical and Religious Directives for Catholic Health Care Services (USCCB 2009, dirs. 30, 33, 49, 51), but the terms and their applications have never been explicitly defined in Catholic documents. Catholic moral theologians have extensively discussed the meaning of these terms and the application of proportionate reason to moral decisions (Hoose 1987), and German theologian Rudolf Ginters provides useful guidelines for assessing an act with both good and bad effects: "(1) preference should be given to the higher value;
(2) quantity must be taken into account as well as quality (e.g., we should implement the kind of rescue operation that will save the greatest number of lives); (3) the more fundamental values should be preferred (life, of course, being one of the most fundamental); (4) the action which has the better chance of success should be preferred; (5) we should protect the values which have the most urgent need of protection" (Ginters 1982, 215-16; Hoose 1987, 86).

Because prescription and use of COC in selected cases will likely accomplish the intended goals of substantially lowering the cancer risk and protecting the fundamental values of life and health in HBOC syndrome mutation carriers, it is proportionately reasoned and judged that the possibility of adverse effects is low, fulfilling the fourth criterion, except for the question of intervals of contraception for those who follow Catholic teaching, which we address below. Finally, short of RRSO with or without hysterectomy, well before many women at increased risk for gynecologic cancer are willing to undergo these operations, there are no surer approaches to reduce the risks than prescription and use of COC, which fulfills the fifth criterion.

\section{Catholic Church Teachings}

Pope Paul VI's (1968) encyclical Humanae vitae teaches that the marriage act has two intrinsic meanings, the procreative and the unitive (nos. 11-13). It further asserts that because contraception violates the procreative meaning of the conjugal act, contraceptive acts are wrong (Paul VI 1968, no. 14). Discerning the multiple effects of medical treatment with the pill, Pope Pius XII (1958), in his 1958 address to the International Congress of Hematology, reasoned that "If a woman takes this medicine not to prevent conception, but only on the advice of a doctor as a necessary remedy because of a disease of the uterus or the organism, she provokes an indirect sterilization, which is permitted according to the general principle of double effect." Reasoning also from the principle of double effect, Pope Paul VI concludes that although contraception is foreseeable but unintended, the use of medical therapies intended to remedy and cure is morally justified: "The Church does not consider at all illicit the use of those therapeutic means necessary to cure bodily diseases, even if a foreseeable impediment to procreation should result there from-provided such impediment is not directly intended for any motive whatsoever" (Paul VI 1968, no. 15). From these papal teachings and finding no significant moral distinction between self-defense, the prevention of 
pregnancy in the cited cases, and the prevention of cancer (Ashley and O'Rourke, 1997, 303; Cahill 2005, 158-59; Grisez 1993, 512; Kelly, Magill, and ten Have 2013, 115; Smith 2016; Tuohey 1990), we discern that if a woman who has inherited a deleterious mutation in BRCA1 or BRCA2 uses COC on the advice of her physician to prevent gynecologic cancer, though the medication also suppresses ovulation, this is permitted according to the principle of double effect. For, as we have seen, these women are highly susceptible to carcinogenic mutations in TP53 that result in distressingly morbid, frequently lethal gynecologic cancers (Casey and Colanta 2016; Crum, McKeon, and Xian 2012; Greenblatt et al. 1994).

Women at high risk for ovarian, fallopian tube, and endometrial cancer and their physician caregivers, weighing the health risks and scrutinizing possible bad effects of using COC for cancer riskreduction, must study and determine whether COC pose significant abortifacient risks. It is inviolable Catholic teaching that human life is sacred (CCC 1994, nos. 53-54). Contemporary science clearly demonstrates that, except for spontaneous miscarriage, injury, and disease, human life naturally progresses seamlessly from the moment of conception (Ashley and O'Rourke 1997, 227-32; England 1996, 2-20; Moore and Persaud 2008; O'Rahilly and Müller 2001; Sadler 2010, 3-112; Schoenwolf et al. 2009). Therefore, anything intended to interrupt the generative process, such as direct abortion, always is morally wrong (CCC 1994, nos. 2270-74; see also, Paul VI 1968, nos. 11-14; Pius XI 1930, nos. 63-64; John Paul II 1995, nos. 60-62).

The good intention of the physician caregiver and the patient herself to reduce the risk of ovarian, fallopian tube, and endometrial cancer coincide with the most basic natural inclination to preserve life (CCC 1994, nos. 2264-65; USCCB 2009, dirs. 2324, 27-29, 33-34). Notwithstanding this inclination and even when medical and personal judgments conclude that the expected good effects are proportionate to potential adverse effects from using COC for risk-reduction in women with great susceptibility to cancer, the foreseeable but unintended contraceptive effects and any significant possibility of disrupting pregnancy are so grave as to demand special diligence in every decision to prescribe and use these medications. The consequences of prescribing and using a medication that would directly assault a human conceptus or developing fetus cannot be justified by the principle of double effect (CCC 1994, nos. 1749-61, 2270-74; Paul VI 1968, no. 14; Pius XI 1930, nos. 63-64; John Paul II 1995, nos. 60-
62). In a recent article, we undertook an intensive review of pertinent published studies (Casey and Salzman 2014) from which we conclude that for women who comply with the medically most commonly used contemporary low-dose monophasic $35-\mu \mathrm{g}$ ethinyl estradiol COC preparations, ovulation rarely if ever occurs and, thus, the potential for conception is negligible or nil (Beck-Fruchter et al. 2012; Bopp and Shoup 1993; Filicori, Butler, and Crowley 1984; Grimes et al. 1994; Hamilton et al. 1985; Kuhl et al. 1985; Landgren and Csemiczky 1991; Larimore and Stanford 2000; Rivera, Yacobson, and Grimes 1999; Spona et al. 1996; Uygur, Alkan, and Batuoğlu 2003; van Vliet et al. 2011).

\section{Conclusion}

Short of premature surgical extirpation of the internal genital organs, which leaves the woman permanently infertile and disposed to the symptoms and physical deteriorations of early menopause, interval use of COC is the surest available method for significantly reducing the risk of gynecologic cancer in genetically susceptible women. When COC are prescribed in compliance with the best standards of medical practice $\mathrm{COC}$ and are used to reduce the risk of gynecologic cancers in HBOC syndrome mutation carriers, we conclude that the more certain prospect of cancer prevention proportionately outweighs the possibility of adverse collateral effects to health (ACOG 2006, 2009, 2010). We reason further, according to the criteria of the principle of double effect, that this intended good proportionately justifies the prescription and use of COC to reduce the risk of cancer in genetically susceptible women, while acknowledging the unintended contraceptive effects of these preparations (Ashley and O'Rourke 1997, 191-92; Casey and Salzman 2014; Gillon 1986; Keenan 1993; O’Donnell 1991, 26-30).

\section{Declaration of Conflicting Interests}

The author(s) declared no potential conflicts of interest with respect to the research, authorship, and/or publication of this article.

\section{Funding}

The author(s) received no financial support for the research, authorship, and/or publication of this article.

\section{References}

Ahmed, A. A., D. Etemadmoghadam, J. Temple, A. G. Lynch, M. Riad, R. Sharma, R. Sharma, et al. 2010. 
"Driver Mutations in TP53 Are Ubiquitous in High Grade Serous Carcinoma of the Ovary." The Journal of Pathology 221 no. 1: 49-56.

ACOG (American College of Obstetricians and Gynecologists). 2006. Use of Hormonal Contraception in Women with Coexisting Medical Conditions, Reaffirmed 2008, ACOG Practice Bulletin, No. 73. http://unmfamilyplanning.pbworks. com/w/file/fetch/82693906/ACOG\%20Bulletin $\% 20 \% 23$ $73 \% 20(1)$.pdf.

ACOG (American College of Obstetricians and Gynecologists). 2009. Hereditary Breast and Ovarian Cancer Syndrome, ACOG Practice Bulletin, No. 103. Obstetrics \& Gynecology 113 no. 4: 957-66.

ACOG (American College of Obstetricians and Gynecologists). 2010. Noncontraceptive Uses of Hormonal Contraceptives. 2010. Noncontraceptive Uses of Hormonal Contraceptives, Reaffirmed 2016, ACOG Practice Bulletin, No. 110. http:// www.acog.org/Resources\%20And\%20Publications/ Practice $\% 20$ Bulletins/Committee $\% 20$ on $\% 20$ Practice $\% 20$ Bulletins\%20Gynecology/Noncontraceptive\%20Uses $\% 20$ of $\% 20$ Hormonal $\% 20$ Contraceptives.aspx.

Andrieu, N., D. E. Goldgar, D. F. Easton, M. Rookus, R. Brohet, A. C. Antoniou, S. Peock, et al. 2006. "Pregnancies, Breast-feeding, and Breast Cancer Risk in the International BRCA1/2 Carrier Cohort Study (IBCCS)." Journal of the National Cancer Institute 98 no. 8: 535-44.

Aquinas, T. 2008. The Summa Theologica of St. Thomas Aquinas, 2nd rev. ed. Translated by Fathers of the English Dominican Province. New Advent Online Edition of 1920 Publication. http://www.newadvent.org/ summa.

Ashley, B. M., and K. D. O'Rourke. 1997. Health Care Ethics: A Theological Analysis, 4th ed. Washington, DC: Georgetown University Press.

Beck-Fruchter, R., A. Weiss, M. Lavee, Y. Geslevich, and E. Shalev. 2012. "Empty Follicle Syndrome: Successful Treatment in a Recurrent Case and Review of the Literature." Human Reproduction 27 no. 5: 1357-67.

Bopp, B., and D. Shoupe. 1993. "Luteal Phase Defects." Journal of Reproductive Medicine 38 no. 5: 348-56.

Boyd, J., Y. Sonoda, M. G. Federici, F. Bogomolniy, E. Rhei, D. L. Maresco, P. E. Saigo, et al. 2000. "Clinicophathologic Features of BRCA-linked and Sporadic Ovarian Cancer." Journal of the American Medical Association 283 no. 17: 2260-65.

Britt, K., and R. Short. 2012. "The Plight of Nuns: Hazards of Nulliparity.” Lancet 379 no. 9834: 2322-23.

Brohet, R. M., D. E. Goldgar, D. F. Easton, A. C. Antoniou, N. Andrieu, J. Chang-Claude, S. Peock, et al. 2007. "Oral Contraceptives and Breast Cancer Risk in the International BRCA1/2 Carrier Cohort Study: A Report from EMBRACE, GENEPSO, GEO-HEBON, and the IBCCS Collaborating Group." Journal of Clinical Oncology 25 no. 25: 3831-36.

Cahill, L. S. 2005. Theological Bioethics: Participation, Justice, Change. Washington, DC: Georgetown University Press.
Cancer Genome Atlas Research Network. 2011. "Integrated Genomic Analysis of Ovarian Carcinoma." Nature 474 no. 7353: 609-15.

Casey, M. J., C. Bewtra, H. T. Lynch, C. Snyder, M. Stacy, and P. Watson. 2013. "Phenotypic Heterogeneity of Hereditary Cancers: A Report from the Creighton Hereditary Cancer Registry." Familial Cancer 12 no. 4: 719-40.

Casey, M. J., C. Bewtra, H. T. Lynch, C. L. Snyder, and M. Stacey. 2015. "Endometrial Cancers in Mutation Carriers from Hereditary Breast Ovarian Cancer Syndrome Kindreds. Report from the Creighton University Hereditary Cancer Registry with Review of the Implications." International Journal of Gynecological Cancer 25 no. 4: 650-56.

Casey, M. J., and A. B. Colanta. 2016. "Müllerian Intraabdominal Carcinomatosis in Hereditary Breast Ovarian Cancer Syndrome: Implications for Risk-reducing Surgery." Familial Cancer 15 no. 3: 371-84.

Casey, M. J., and T. A. Salzman. 2014. "Therapeutic, Prophylactic, Untoward, and Contraceptive Effects of Combined Oral Contraceptives: Catholic Teaching, Natural Law, and the Principle of Double Effect When Deciding to Prescribe and Use." American Journal of Bioethics 14 no. 7: 20-34.

Catechism of the Catholic Church (CCC). 1994. English translation. Liguori, MO: Liguori Press.

Chen, S., and G. Parmigiani. 2007. "Meta-analysis of BRCA1 and BRCA2 Penetrance." Journal of Clinical Oncology 25 no. 11: 1329-33.

Cibula, D., A. Gompel, A. O. Mueck, C. LaVeccia, P. C. Hannaford, S. O. Skouby, M. Zikan, and L. Dusek. 2010. "Hormonal Contraception and Risk of Cancer." Human Reproduction Update 16 no. 6: 631-50.

Cibula, D., M. Zilkan, L. Dusek, and O. Majek. 2014. “Oral Contraceptives and Risk of Ovarian and Breast Cancers in BRCA Mutation Carriers: A Meta-analysis." Expert Review of Anticancer Therapy 11 no. 8: 1197-207.

Clark, P. M. 2014. "Defining the Scope of Casey and Salzman's Application of the Rule of Double Effect to the Therapeutic and Prophylactic Uses of Combined Oral Contraceptives." American Journal of Bioethics 14 no. 7: 35-38.

CGESOC (Collaborative Group on Epidemiological Studies of Ovarian Cancer). 2008. "Ovarian Cancer and Oral Contraceptives: Collaborative Reanalysis of Data from 45 Epidemiological Studies Including 23257 Women with Ovarian Cancer and 87303 Controls." Lancet 371 no. 9606: 303-14.

CGHFBC (Collaborative Group on Hormonal Factors in Breast Cancer). 1996. "Breast Cancer and Hormonal Contraceptive: Collaborative Reanalysis of Individual Data on 53297 Women with Breast Cancer and 100 239 Women without Breast Cancer from 54 Epidemiological Studies." Lancet 347 no. 9017: 1713-727.

Crum, C. P., F. D. McKeon, and W. Xian. 2012. "BRCA, the Oviduct, and the Space and Time Continuum of Pelvic Serous Carcinogenesis." International Journal of Gynecological Cancer 22no. S1: S29-S34. 
Cullinane, C. A., J. Lubinski, S. L. Neuhausen, P. Ghadirian, H. T. Lynch, C. Isaacs, B. Weber, et al. 2005. "Effect of Pregnancy as a Risk Factor for Breast Cancer in BRCA1/BRCA2 Mutation Carriers." International Journal of Cancer 117 no. 6: 988-91.

Daly, M. B., J. E. Axilbund, S. Buys, B. Crawford, C. D. Farrell, S. Friedman, J. E. Garber, et al. 2010. "Genetic/Familial High-risk Assessment: Breast and Ovarian." Journal of the National Comprehensive Cancer Network 8 no. 5: 562-94. http://www.jnccn.org/con tent $/ 8 / 5 / 562$.full.pdf + html.

Eisen, A., J. Lubinski, J. Gronwald, P. Moller, H. T. Lynch, J. Klijn, C. Kim-Sing, et al. 2008. "Hormone Therapy and the Risk of Breast Cancer in BRCA1 Mutation Carriers." Journal of the National Cancer Institute 100 no. 19: 1361-67.

England, M. A. 1996. Life before Birth, 2nd ed. London, UK: Mosby-Wolfe.

ESHRE Capri Workshop Group. 2004. "Hormones and Breast Cancer." Human Reproduction Update 10 no. 4: 281-93.

Evans, D. G., K. N. Gaarenstroom, D. Stirling, A. Shenton, L. Maehle, A. Dørum, M. Steel, et al. 2009. "Screening for Familial Ovarian Cancer: Poor Survival of BRCA1/ 2 Related Cancers." Journal of Medical Genetics 46 no. 9: 593-97.

Fakkert, I. E., E. M. Abma, I. G. Westrik, J. D. Lefrandt, B. H. Wolffenbuttel, J. C. Oosterwijk, R. H. Slart, et al. 2015. "Bone Mineral Density and Fractures after Risk-reducing Salpingo-oophorectomy in Women at Increased Risk for Breast and Ovarian Cancer." European Journal of Cancer 51 no. 3: 400-08.

Falconer, H., L. Yin, H. Grönberg, and D. Altman. 2015. "Ovarian Cancer Risk after Salpingectomy: A Nationwide Population-based Study." Journal of the National Cancer Institute 107 no. 4: dju490. doi: 10.1093/jnci/ dju410.

Filicori, M., J. P. Butler, and W. F. Crowley, Jr. 1984. "Neuroendocrine Regulation of the Corpus Luteum in the Human." Journal of Clinical Investigation 73 no. 6: $1638-47$.

Finch, A., G. Evans, and S. A. Narod. 2012. "BRCA Carriers, Prophylactic Salpingo-oophorectomy and Menopause: Clinical Management Considerations and Recommendations." Women's Health 8 no. 5: 543-53.

Finch, A. P., J. Lubinski, P. Møller, C. F. Singer, B. Karlan, L. Senter, B. Rosen, et al. 2014. "Impact of Oophorectomy on Cancer Incidence and Mortality in Women with a BRCA1 or BRCA2 Mutation." Journal of Clinical Oncology 32 no. 15: 1547-53.

Fishman, A. 2010. "The Effects of Parity, Breastfeeding, and Infertility Treatment on the Risk of Hereditary Breast and Ovarian Cancer. A Review." International Journal of Gynecologic Cancer 20no. S2: S31-S33.

Fraumeni, J. F., Jr., J. W. Lloyd, E. M. Smith, and J. K. Wagoner. 1969. "Cancer Mortality among Nuns: Role of Marital Status in Etiology of Neoplastic Disease." Journal of the National Cancer Institute 42 no. 3 : 455-68.
Friebel, T. M., S. M. Domchek, and T. R. Rebbeck. 2014. "Modifiers of Cancer Risk in BRCA1 and BRCA2 Mutation Carriers: A Systematic Review and Meta-analysis." Journal of the National Cancer Institute 106 no. 6: dju091. doi: 10.1093/jnci/dju091.

Ford, D., D. F. Easton, M. Stratton, S. Narod, D. Goldgar, P. Devilee, D. T. Bishop, et al. 1998. "Genetic Heterogeneity and Penetrance Analysis of the BRCA1 and BRCA2 Genes in Breast Cancer Families." American Journal of Human Genetics 62 no. 3: 676-89.

Ghoos, J. 1951. "L'Acte a double effet: Etude de theologie Positive." Ephemerides Theologicae Lovanienses 27 no. 1: 30-52.

Gillon, R. 1986. "The Principle of Double Effect and Medical Ethics.” British Medical Journal 292 no. 6514: 193-94.

Ginters, R. 1982. Werte und Normen: Einführung in die philosophische und theologische Ethik. Dusseldorf, Germany: Wandenhoek und Ruprecht.

Greenblatt, M. S., W. P. Bennet, M. Hollstein, and C. C. Harris. 1994. "Mutations in the p53 Tumor Suppressor Gene: Clues to Cancer Etiology and Molecular Pathogenesis." Cancer Research 54 no. 18: 4855-78.

Grimes, D. A., A. J. Godwin, A. Rubin, J. A. Smith, and M. Lacarra. 1994. "Ovulation and Follicular Development Associated with Three Low-dose Oral Contraceptives: A Randomized Controlled Trial." Obstetrics and Gynecology 83 no. 1: 29-34.

Grisez, G. 1965. "The First Principle of Practical Reason: A Commentary on the Summa Theologica, 1-2, Question 94, Article 2." Natural Law Forum 10:168-201. http:// www.twotlj.org/fppr.pdf.

Grisez, G. 1993. The Way of the Lord Jesus, vol. 2, Living a Christian Life. Quincy, IL: Franciscan Press.

Gross, A. L., R. J. Kurman, R. Vang, Ie-M. Shih, and K. Visvanathan. 2010. "Precursor Lesions of High-grade and Serous Ovarian Carcinoma: Morphological and Molecular Characteristics." Journal of Oncology 2010: 126295 Article ID 126295, 9. doi: 10.1155/ 2010/126295.

Gula, R. M. 1989. Reason Informed by Faith: Foundations of Catholic Morality. Mahwah, NJ: Paulist Press.

Hamilton, C. J. C. M., L. C. G. Wetzels, J. L. H. Evers, H. T. Hoogland, A. Muijtjens, and J. de Haan. 1985. "Follicle Growth Curves and Hormonal Patterns in Patients with the Luteinized Unruptured Follicle Syndrome." Fertility and Sterility 43 no. 4: 541-48.

Hannaford, P. C., L. Iversen, T. V. Macfarlane, A. M. Elliot, V. Angus, and A. J. Lee. 2010. "Mortality among Contraceptive Pill Users: Cohort Evidence from Royal College of General Practitioners' Oral Contraceptive Study." British Journal of Medicine 340: c927. http:// www.bmj.com/content/340/bmj.c927.

Hoose, B. 1987. Proportionalism: The American Debate and Its European Roots. Washington, DC: Georgetown University Press.

Howitt, B. E., S. Hanamornroongruang, D. I. Lin, J. E. Conner, S. Schulte, N. Horowitz, C. P. Crum, and E. E. Meserve. 2015. "Evidence for a Dualistic Model of 
High-grade Serous Carcinoma: BRCA Mutation Status, Histology, and Tubal Intraepithelial Carcinoma." American Journal of Surgical Pathology 39 no. 3: 287-93.

Iodice, S., M. Barile, N. Rotmensz, I. Feroce, B. Bonanni, P. Radice, L. Bernard, P. Maisonneuve, and S. Gandini. 2010. "Oral Contraceptive Use and Breast of Ovarian Cancer Risk in BRCA1/2 Carriers: A Meta-analysis." European Journal of Cancer 46 no. 12: 2275-84.

Jernström, H., C. Lerman, P. Ghadirian, H. T. Lynch, B. Weber, J. Garber, M. Daly, et al. 1999. "Pregnancy and Risk of Early Breast Cancer in Carriers of BRCA1 and BRCA2." Lancet Oncology 354no. 9193: 1846-50.

John Paul II, Pope. 1993. Veritatis splendor. http://w2.vati can.va/content/john-paul-ii/en/encyclicals/documents/ hf_jp-ii_enc_06081993_veritatis-splendor.html.

John Paul II, Pope. 1995. Evangelium vitae. http://w2.vati can.va/content/john-paul-ii/en/encyclicals/documents/ hf_jp-ii_enc_25031995_evangelium-vitae.html.

Kahlenborn, C., F. Modugno, D. M. Potter, and W. B. Severs. 2006. "Oral contraceptive Use as Risk Factor for Premenopausal Breast Cancer: A Meta-analysis." Mayo Clinic Proceedings 81 no. 10: 1290-302.

Karnezis, A. N., A. Aysal, C. J. Zaloudek, and J. T. Rabban. 2013. "Transitional Cell-like Morphology in Ovarian Endometrioid Carcinoma: Morphologic, Immunohistochemical, and Behavioral Features Distinguishing It from High-grade Serous Carcinoma." American Journal of Surgical Pathology 37 no. 1: 24-37.

Kauff, N. D., J. M. Satagopan, M. E. Robson, L. Scheuer, M. Hensley, C. A. Hudis, N. A. Ellis, et al. 2002. "Risk-reducing Salpingo-oophorectomy in Women with a BRCA1 or BRCA2 Mutation." New England Journal of Medicine 346 no. 21: 1609-15.

Keenan, J. F. 1993. "The Function of the Principle of Double Effect.” Theological Studies 54 no. 2: 294-315.

Kelly, D. F., G. Magill, and H. ten Have. 2013. Contemporary Catholic Health Care Ethics. Washington, DC: Georgetown University Press.

Kocjan, T., and G. M. Prelevic. 2003. "Hormone Replacement Therapy Update: Who Should We Be Prescribing This to Now?" Current Opinion in Obstetrics and Gynecology 15 no. 6: 459-64.

Kostopoulos, J., J. Lubinski, P. Moller, H. T. Lynch, C. F. Singer, C. Eng, S. L. Neuhausen, et al. 2014. "Timing of Oral Contraceptive Use and the Risk of Breast Cancer in BRCA1 Mutation Carriers." Breast Cancer Research and Treatment 143 no. 3: 579-86.

Kotsopoulos, J., J. Gronwald, B. Y. Karlan, T. Huzarski, N. Tung, P. Moller, S. Armel, et al. 2018. "Hormone Replacement Therapy after Oophorectomy and Breast Cancer Risk among BRCA1 Mutation Carriers.” JAMA Oncology. Published online ahead of print April 19. doi: 10.1001/jamaoncol.2018.0211.

Kotsopoulos, J., J. Lubinski, J. Gronwald, C. Cybulski, R. Demsky, S. L. Neuhausen, C. Kim-Sing, et al. 2015. "Factors Influencing Ovulation and the Risk of Ovarian Cancer in BRCA1 and BRCA2 Mutation Carriers." International Journal of Cancer 137 no. 5: 1136-46.
Kotsopoulos, J., J. Lubinski, H. T. Lynch, J. Klijn, P. Ghadirian, S. L. Neuhausen, C. Kim-Sing, et al. 2007. “Age at First Birth and the Risk of Breast Cancer in BRCA1 and BRCA2 Mutation Carriers." Breast Cancer Research and Treatment 105 no. 2: 221-28.

Kuhl, H., G. Gahn, G. Romberg, W. März, and H.-D. Taubert 1985. "A Randomized Cross-over Comparison of Two Low-dose Oral Contraceptives upon Hormonal and Metabolic Parameters: I. Effects upon Sexual Hormone Levels." Contraception 31 no. 6: 583-93.

Kurman, R. J., M. L. Carcangiu, C. S. Herrington, and R. H. Young. 2014. WHO Classification of Tumours of Female Reproductive Organs, 4th ed., 15-43, 88-110. Lyon, France: International Agency for Research in Cancer, WHO Press.

Landgren, B. M., and G. Csemiczky. 1991. "The Effect on Follicular Growth and Luteal Function of "Missing the Pill." A Comparison between a Monophasic and a Triphasic Combined Oral Contraceptive." Contraception 43 no. 2: $149-59$.

Larimore, W. L., and J. B. Stanford. 2000. "Postfertilization Effects of Oral Contraceptives and Their Relationship to Informed Consent." Archives of Family Medicine 9 no. 2: 126-33.

Lux, M. P., P. A. Fasching, and M. W. Beckmann. 2006. "Hereditary Breast and Ovarian Cancer: Review and Future Perspectives." Journal of Molecular Medicine 84 no. 1: 16-28.

Lynch, H.T., M. J. Casey, C. L. Snyder, C. Bewtra, J. F. Lynch, M. Butts, and A. K. Godwin. 2009. "Hereditary Ovarian Carcinoma: Heterogeneity, Molecular Genetics, Pathology, and Management." Molecular Oncology 3 no. 2: $97-137$.

Mangan, J. 1949. "An Historical Analysis of the Principle of Double Effect." Theological Studies 10 no. 1: 41-61.

Maquire, K., and C. Westhoff. 2011. "The State of Hormonal Contraception Today: Established and Emerging Noncontraceptive Health Benefits." American Journal of Obstetrics and Gynecology 205 no. 4 Suppl.: S4-S8.

Marchbanks, P. A., J. A. McDonald, H. G. Wilson, S. G. Folger, M. G. Mandel, J. R. Daling, L. Bernstein, et al, . 2002 "Oral Contraceptives and the Risk of Breast Cancer." New England Journal of Medicine 346 no. 26: 2025-32.

Marchetti, C., F. De Felice, I. Palaia, G. Perniola, A. Musella, D. Musio, L. Muzii, V. Tombolini, and P. B. Panici. 2014a. "Risk-reducing Salpingo-oophorectomy: A Meta-analysis on Impact on Ovarian Cancer Risk and All Cause Mortality in BRCA 1 and BRCA 2 Mutation Carriers." BioMed Central Women's Health 14: 150. http://www.biomedcentral.com/1472-6874/14/150.

Marchetti, C., R. Iadarola, I. Palaia, V. di Donato, G. Perniola, L. Muzii, and P. B. Planica. 2014b. "Hormone Therapy in Oophorectomized BRCA1/2 Mutation Carriers." Menopause 21 no. 7: 763-68.

Mathews, T. J., and B. E. Hamilton. 2016. Mean Age of Mothers Is on the Rise: United States. 2000-2014. HCHS Data Brief, No. 232, U. S. Department of Health and Human Services. Centers for Disease Control and 
Prevention. National Center for Health Statistics. https://www.cdc.gov/nchs/data/databriefs/db232.pdf.

McCormick, R. A. 1981. "Bioethics and Method: Where Do We Start?” Theology Digest 29 no. 4: 303-18.

McLaughlin, J. R., H. A. Risch, J. Lubinski, P. Moller, P. Ghadirian, H. Lynch, B. Karlan, et al. 2007. "Reproductive Risk Factors for Ovarian Cancer in Carriers of BRCA1 or BRCA2 Mutations: A Case-control Study." Lancet Oncology 8 no. 1: 26-34.

Milne, R. L., J. A. Knight, E. M. John, G. S. Dite, R. Balbuena, A. Ziogas, I. L. Andrulis, et al. 2005. "Oral Contraceptive Use and Risk of Early-onset Breast Cancer in Carriers and Noncarriers of BRCA1 and BRCA2 Mutations." Cancer Epidemiology, Biomarkers and Prevention 14 no. 2: 350-56.

Milne, R. L., A. Osorio, T. Ramón y Cajal, M. Baiget, A. Lasa, E. Diaz-Rubio, M. de la Hoya, et al. 2010. "Parity and the Risk of Breast and Ovarian Cancer in BRCA1 and BRCA2 Mutation Carriers." Breast Cancer Research and Treatment 119 no. 1: 221-32.

Modan, B., P. Hartge, G. Hirsh-Yechezkel, A. Chetrit, F. Lubin, U. Beller, G. Ben-Baruch, et al. 2001. "Parity, Oral Contraceptives, and the Risk of Ovarian Cancer among Carriers and Noncarriers of a BRCA1 or BRCA2 Mutation." New England Journal of Medicine 345 no. 4: 235-40.

Moore, K. L., and T.V.N. Persaud. 2008. Before We Are Born: Essentials of Embryology and Birth Defects, 4th ed. Philadelphia, PA: W.B. Saunders.

Moorman, P. G., L. J. Havrilesky, J. M. Gierisch, R. R. Coeytaux, W. J. Lowery, R. P. Urrutia, M. Dinan, et al. 2013. "Oral Contraceptives and Risk of Ovarian Cancer and Breast Cancer among High-risk Women: A Systematic Review and Meta-analysis." Journal of Clinical Oncology 31 no. 33: 4188-98.

Moorman, P. G., E. S. Iversen, P. K. Marcom, J. R. Marks, F. Wang, E. Lee, G. Ursin, et al. 2010. "Evaluation of Established Breast Cancer Risk Factors as Modifiers of BRCA1 or BRCA2: A Multi-center Case-only Analysis." Breast Cancer Research and Treatment 124 no. 2: 441-51.

Narod, S. A. 2011. "Hormone Replacement Therapy and the Risk of Breast Cancer." Nature Reviews Clinical Oncology 8 no. 11: 669-76.

Narod, S. A., M.-P. Dubé, J. Klijn, J. Lubinski, H. T. Lynch, P. Ghadirian, D. Provencher, et al. 2002. "Oral Contraceptives and the Risk of Breast Cancer in BRCA1 and BRCA2 Mutation Carriers." Journal of the National Cancer Institute 94 no. 23: 1773-79.

Ness, R. B., J. A. Grisso, J. Klapper, J. J. Schlesselman, S. Silberzweig, S. Silberzweig, R. Vergona, M. Morgan, and J. E. Wheeler. 2000. "Risk of Ovarian Cancer in Relation to Estrogen and Progestin Dose and Use Characteristics of Oral Contraceptives." American Journal of Epidemiology 152 no. 3: 233-41.

O’Donnell, T. J. 1991. Medicine and Christian Morality, 2nd ed. New York: Alba House.

O'Rahilly, R. R., and F. Müller. 2001. Human Embryology \& Teratology, 3rd ed. Wilmington, DE: Wiley-Liss.
Paul VI, Pope. 1968. Humanae Vitae. http://w2.vatican.va/ content/paul-vi/en/encyclicals/documents/hf_p-vi_ enc_25071968_humanae-vitae.html.

Petrucelli, N., M. B. Daly, and G. L. Feldman. 2010. "Hereditary Breast and Ovarian Cancer Due to Mutations in BRCA1 and BRCA2." Genetics in Medicine 12 no. 5: 245-59.

Phelan, C. M., K. B. Kuchenbaecker, J. P. Tyrer, S. P. Kar, K. Lawrenson, S. J. Winham, J. Dennis, et al. 2017. "Identification of 12 New Susceptibility Loci for Different Histotypes of Epithelial Ovarian Cancer." Nature Genetics 49 no. 5: 680-89. https://www.nature.com/ng/ journal/v49/n5/pdf/ng.3826.

Piek, J. M., B. Torrenga, B. Hermsen, R. H. Verheijen, R. P. Zweemer, J. J. Gille, P. Kenemans, P. J. van Diest, and F. H. Menko. 2003. "Histopathological Characteristics of BRCA1- and BRCA2-associated Intraperitoneal Cancer: A Clinic-based Study." Familial Cancer 2 no. 2: 73-78.

Pius XI, Pope. 1930. Casti connubii. https://w2.vatican.va/ content/pius-xi/en/encyclicals/documents/hf_p-xi_ enc_19301231_casti-connubii.html.

Pius XII, Pope. 1958. "Address to Participants in the Seventh International Congress of Hematology, September 12." https://w2.vatican.va/content/piusxii/fr/ speeches/1958/documents/hf_p-xii_spe_19580912_ ematologia.html.

Poole, E. M., M. S. Rice, C. P. Crum, and S. S. Tworoger. 2015. "Salpingectomy as a Potential Ovarian Cancer Risk-reducing Procedure." Journal of the National Cancer Institute 107 no. 2: dju490. doi: 10.1093/jmci/ dju490.

Pruthi, S., B. S. Gostout, and N. M. Lindor. 2010. "Identification and Management of Women with BRCA Mutations or Hereditary Predisposition for Breast and Ovarian Cancer." Mayo Clinic Proceedings 85 no. 12: 1111-20.

Purdie, D. M., C. J. Brain, V. Siskind, P. M. Webb, and A. C. Green. 2003. "Ovulation and Risk of Epithelial Ovarian Cancer." International Journal of Cancer 104 no. 2: 228-32.

Rebbeck, T. R., T. Friebel, T. Wagner, H. T. Lynch, J. E. Garber, M. B. Daly, C. Isaacs, et al. 2005. "Effect of Short-term Hormone Replacement Therapy on Breast Cancer Risk Reduction after Bilateral Prophylactic Oophorectomy in BRCA1 and BRCA2 Mutation Carriers: The PROSE Study Group." Journal of Clinical Oncology 23 no. 31: 7804-10.

Rebbeck, T. R., N. D. Kauff, and S. M. Domchek. 2009. "Meta-analysis of Risk Reduction Estimates Associated with Risk-reducing Salpingo-oophorectomy in BRCA1 or BRCA2 Mutation Carriers." Journal of the National Cancer Institute 101 no. 2: 80-87.

Rebbeck, T. R., H. T. Lynch, S. L. Neuhausen, S. A. Narod, L. Van't Veer, J. E. Garber, G. Evans, et al. 2002. "Prophylactic Oophorectomy in Carriers of BRCA1 or BRCA2 Mutations." New England Journal of Medicine 346 no. 21: 1616-22. 
Ritterhouse, L. L., J. A. Nowak, K. C. Strickland, E. P. Garcia, Y. Jia, N. I. Lindeman, L. E. Macconaill, et al. 2016. "Morphologic Correlates of Molecular Alterations in Extrauterine Müllerian Carcinomas." Modern Pathology 29 no. 8: 893-903.

Rivera, C. M., B. R. Grossardt, D. J. Rhodes, R. D. Brown Jr., V. L. Roger, L. J. Melton III, and W. A. Rocca. 2009. "Increased Cardiovascular Mortality after Early Bilateral Oophorectomy.” Menopause 16 no. 1: 15-23.

Rivera, R., I. Yacobson, and D. Grimes. 1999. "The Mechanism of Action of Hormonal Contraceptives and Intrauterine Devices." American Journal of Obstetrics and Gynecology 181 no. 5 pt. 1: 1263-69.

Sadler, T. W. 2010. Langman's Medical Embryology, 11th ed. Baltimore, MD: Lippincott Williams \& Wilkins.

Schierbeck, L. L., L. Rejnmark, C. L. Tofteng, L. Stilgren, P. Eiken, L. Mosekilde, L. Køber, and J. E. Jensen. 2012. "Effect of Hormone Replacement Therapy on Cardiovascular Events in Recently Postmenopausal Women: Randomised Trial.” British Medical Journal 345:e6409.

Schildkraut, J. M., B. Calingaert, P. A. Marchbanks, P. G. Moorman, and G. C. Rodriguez. 2002. "Impact of Progestin and Estrogen Potency in Oral Contraceptives on Ovarian Cancer Risk." Journal of the National Cancer Institute 94 no. 1: 32-38.

Schoenwolf, G. C., S. B. Bleyl, P.R. Brauer, and F. H. Francis-West. 2009. Larsen's Human Embryology, 4th ed. Philadelphia, PA: Churchill Livingstone Elsevier.

Singh, N., C. B. Gilks, N. Wilkinson, and W. G. McCluggage. 2015. "The Secondary Müllerian System, Field Effect, BRCA, and Tubal Fimbria: Our Evolving Understanding of the Origin of Tubo-ovarian Highgrade Serous Carcinoma and Why Assignment of Primary Sites." Pathology 47 no. 5: 423-31.

Skates, S. J. 2012. "OCS: Development of the Risk of Ovarian Cancer Algorithm (ROCA) and ROCA Screening Trials." International Journal of Cancer 22 no. Suppl. 1: S24-26. https://www.ncbi.nlm.nih.gov/pmc/ articles/PMC3572791/pdf/nihms367811.pdf.

Skates, S. J., M. H. Greene, S. S. Buys, P. L. Mai, P. Brown, M. Piedmonte, G. Rodriguez, et al. 2017. "Early Detection of Ovarian Cancer Using the Risk of Ovarian Cancer Algorithm with Frequent CA125 Testing in Women at Increased Familial Risk-Combined Results from Two Screening Trials." Clinical Cancer Research. http://clincancerres.aacrjournals.org/content/clin canres/early/2017/05/03/1078-0432.CCR-15-2750.full. pdf.

Smith, J. 2016. "Did Paul VI Approve of Congo Nuns Using the Pill? Does It Matter If He Didn't?" The Catholic World Report. http://www.catholicworldreport. com/2016/02/27/did-paul-vi-approve-of-congo-nunsusing-the-pill-does-it-matter-if-he-didnt/.

Snyder, C. L., M. J. Casey, and H. T. Lynch. 2015. "Should Risk-reducing Surgery in Women from Hereditary Breast Ovarian Cancer Families Be Confined to Removal of the Fallopian Tube with Ovarian Conservation?" Women's Health 11 no. 4: 423-27.
Soslow, R. A., G. Han, K. J. Park, K. Garg, N. Olvera, D. R. Spriggs, N. D. Kauff, and D. A. Levine. 2012. "Morphologic Patterns Associated with BRCA1 and BRCA2 Genotype in Ovarian Carcinoma." Modern Pathology 25 no. 4: 625-36.

Spona, J., W. Feichtinger, Ch. Kindermann, C. Wünsch, and K. Brill. 1996. "Inhibition of Ovulation by an Oral Contraceptive Containing $100 \mathrm{mg}$ Levonorgestrel in Combination with $20 \mathrm{mg}$ Ethinylestradiol." Contraception 54 no. 5: 299-304.

Toss, A., G. Grandi, A. Cagnacci, L. Marcheselli, S. Pavesi, E. De Matteis, E. Razzaboni, C. Tomasello, S. Cascinu, and L. Cortesi. 2017. "The Impact of Reproductive Life on Breast Cancer Risk in Women and Family History of BRCA Mutation.” Oncotarget 8 no. 6: 9144-54.

Tung, K. H., L. R. Wilkens, A. H. Wu, K. McDuffie, A. M. Nomura, L. N. Kolonel, K. Y. Terada, and M. T. Goodman. 2005. "Effect of Anovulation Factors on Pre- and Postmenopausal Ovarian Cancer Risk: Revisiting the Incessant Ovulation Hypothesis." American Journal of Epidemiology 161 no. 4: 321-29.

Tuohey, J. 1990. "Methodology or Ideology: The Condom and a Consistent Sexual Ethic." Louvain Studies 15 no. 1990: 53-69.

USCCB (United States Conference of Catholic Bishops). 2009. Ethical and Religious Directives for Catholic Health Care Services, 5th ed. http://www.usccb.org/ issues-and-action/human-life-and-dignity/health-care/ upload/Ethical-Religious-Directives-Catholic-HealthCare-Services-fifth-edition-2009.pdf.

U. S. Preventive Services Task Force. 2012. Final Recommendation Statement: Ovarian Cancer: Screening. https://www.uspreventiveservicestaskforce.org/Page/ Document/RecommendationStatementFinal/ovariancancer-screening.

Uygur, D., R. N. Alkan, and S. Batuoğlu. 2003. "Recurrent Empty Follicle Syndrome.” Journal of Assisted Reproduction and Genetics 20 no. 9: 390-92.

Vang, R., D. A. Levine, R. A. Soslow, C. Zaloudek, Ie-M. Shih, and R. J. Kurman. 2016. "Molecular Alterations of TP53 Are a Defining Feature of Ovarian Highgrade Serous Carcinoma: A Rereview of Cases Lacking TP53 Mutations in the Cancer Genome Atlas Ovarian Study." International Journal of Gynecological Pathology 35 no. 1: 48-55.

van Vliet, H. A., D. A. Grimes, L. M. Lopez, K. F. Schulz, and F. M. Helmerhorst. 2011, November 9. "Triphasic Versus Monophasic Oral Contraceptives for Contraception." Cochrane Database of Systematic Reviews, Issue 11. http://apps.who.int/rhl/reviews/langs/CD003553. pdf.

Vatican Council II. 1965a. Dignitatis humanae. Declaration on Religious Freedom. http://www.vatican.va/ archive/hist_councils/ii_vatican_council/documents/ vat-ii_decl_19651207_dignitatis-humanae_en.html.

Vatican Council II. 1965b. Gaudium et spes. Pastoral Constitution of the Church in the Modern World. http:// www.vatican.va/archive/hist_councils/ii_vatican_coun 
cil/documents/vat-ii_const_19651207_gaudium-etspes_en.html.

Vessey, M., and R. Painter. 2006. "Oral Contraceptive Use and Cancer: Findings in a Large Cohort Study, 19682004." British Journal of Cancer 95 no. 3: 385-89.

Vessey, M., D. Yeates, and S. Flynn. 2010. "Factors Affecting Mortality in a Large Cohort Study with Reference to Oral Contraceptive Use." Contraception 82 no. 3 : 221-29.

Walter, J. J. 1990. "The Foundation and Formulation of Norms." In Moral Theology: Challenges for the Future, edited by C. E. Curran, 125-54. Mahwah, NJ: Paulist Press.

Weiderpass, E., and J. E. Tyczynski. 2015. "Epidemiology of Patients with Ovarian Cancer with and without a BRCA1/2 Mutation." Molecular Diagnosis and Therapy 19 no. 6: 351-64.
Whittemore, A. S., R. R. Balise, P. D. P. Pharoah, R. A DiCioccio, I. Oakley-Girvan, S. J. Ramus, M. Daly, et al. 2004. "Oral Contraceptive Use and Ovarian Cancer Risk among Carriers of BRCA1 or BRCA2 Mutations." British Journal of Cancer 91 no. 11: 1911-15.

\section{Biographical Notes}

Murray Joseph Casey, MD, MS, MBA, PhD, is a professor of Obstetrics and Gynecology with certification of special competence in gynecologic oncology and a professor of Preventive Medicine and Public Health in the School of Medicine, Creighton University.

Todd A. Salzman, PhD, MA, STB, is the endowed Amelia and Emil Graff professor of Catholic theology in the Department of Theology, Creighton University. 